Tips om medisinsk litteratur, andre bøker, filmer og elektroniske medier som bør anmeldes, sendes tidsskriftet@legeforeningen.no

\section{Kunsten at dø}

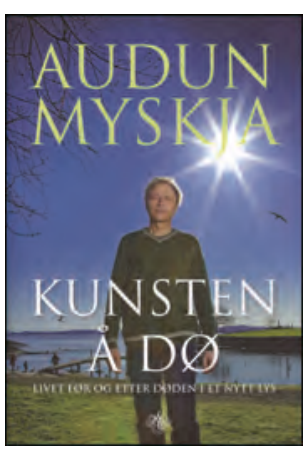

\section{Audun Myskja}

\section{Kunsten å dø}

Livet $f ø r$ og etter $d \varnothing d e n$ i et nytt lys. 336 s, ill.

Oslo: J.M. Stenersens Forlag, 2012.

Pris NOK 349

ISBN 978-82-7201-543-4
Nøgleordet i titlen, «Kunsten», er i nordiske sprog afledt af at «kunne», dvs. at «formå», men substantiveret har det en tillægsbetydning af «kunstnerisk» eller «artistisk». Hermed sker der så også en vis sløring af den nødvendige flertydighed, som biologisk indsigt, mod, medmenneskelighed, og social opmærksomhed.

Audun Myskja inddrager dette større perspektiv ved beskrivelsen af målgruppen: At læsernes forhold til døden, via erfaring og modning, gør det personlige i livet almengyldigt, bidrager til bedre omsorg for døende og udvider dermed dødens perspektiv, «så at døden kan lære os om livet».

Som ung læge oplevede forfatteren en klinisk nærdødsoplevelse, som gjorde, at mødet med patientdøden i flere sammenhænge ændrede døden «fra noget trivielt til noget eksistentielt» i valget af hans fremtidige arbejds- og interesseopgaver.

I kapitel 1 er forfatteren nået til erkendelsen af, at han nu ændrer sit syn på døden fra at være tab og nederlag til «at døden åbner en mulighed for at forløse os». I kapitlet beskriver forfatteren også sitt lange ophold på en irsk antroposofisk gård, selv lidende af en svær, livstruende, nervøs spisevægring, som han dog overlever.

I denne livsfase dukker også lysfænomener op i skikkelse af et lysvæsen, der også er en samtalepartner, som på forfatterens spørgsmål om de åndsvidenskabelige lysfænomeners mening svarer: «Til at velsigne og helbrede andre mennesker».

Kapitel 2 har titlen $\AA$ helbrede dimensjoner som dødens gave. Patienten Sara's kræftsygdom fik hende til at konkludere, «at hun for første gang i sit liv oplevede tilgivelse og forsoning». Og at hun også har oplevet en genopvoksende barnetro og en genhørt salme. Kapitlet rummer også sande eksempler på livsvaner som er tabskilder, og omfatter også små børns møde med døden.

Døden er individuel. Hver dødsproces har sit særlige præg, som fingeraftryk. I kapitel 5, Hvordan d $\phi r v i$ ?, inddeles de hyppigste dødsårsager ud fra såkaldt klinisk diagnostik og de forskellige sygdomsstadier.

Kapitel 6, Hva kan vi gjøre for å hjelpe?, indledes med en vigtig afklaring: God dødspleje er ikke aktiv dødshjælp. Det er heller ikke livsforlængende behandling. Målet er at lindre plagerne, uden at «dope» den døende. Husk at særligt ældre sover ind uden behov for lindrende lægemiddelbehandling. God dødspleje handler lige så meget om holdninger som om medikamenter.
Fatigúe, afmagt, træthed og slaphed skal også behandles, men er næppe muligt via de fysiske gøremål, som er angivet i bogens tegninger - og her uden støtte af et evidensskabende, statistisk apparat.

«Vi dør ikke, verden dør fra oss» er det indledende citat fra Edvard Munch i kapitel 7, Livet etter dфden - finnes det?. Kapitlet udgør en skæbnebelyst beskrivelse og diskussion af svar som ikke kendes i evidensbaseret form, selv ikke ved gennemgangen af tre rapporter fra den videnskabelige litteratur. Henvisningen til nærdødsbeskrivelser, som beskrives, bringer ikke evidensbaserede svar.

I kapitel 9, Hva kan dфden laere oss?, gennemgår forfatteren dødens eksistentielle perspektiver, med baggrund i hans patientoplevelser. Det sker ud fra et citat af min egen ungdoms store svenske lyriker, Karin Boye, som tog sit eget liv:

«Tänk att nu vara död och ha lämnat bakom sig allt, Ångest, fase och ensamhet, och den oförsonlige skulden. Men en stor rättvisa ligger gömd på botten av tingen. Alla har vi en nåd att vänte - en gåva som ingen rövar.»

Kapitel 10, Kjarligheten overlever d $\phi$ den, er skrevet til minde om Erik Schnell (1966-2011). Forfatterens ven, erindret gennem følgende digt, og via en bevægende mindekrønike om Erik Schnells liv og hans familie. Dette kapitel yder sit særlige bidrag til nordisk kultur og menneskesyn, og har ifølge anmelderen været bogens mest værdifulde eksistentielle bidrag til dens internationale og videnskabelig indsigter i dens fremhævede begreber: livet, karligheden og døden.

\section{Povl Riis}

Odense

Danmark 